\title{
Hills, Huts, and Horse-Teams: The New Jersey Environment and Continental Army Winter Encampments, 1778-1780
}

\section{By Steven Elliott}

\section{DOI: http://dx.doi.org/10.14713/njs.v3i1.67}

New Jersey's role as a base for the Continental Army during the War of Independence has played an important part in the state's understanding of its role in the American Revolution, and continues to shape the state's image as the "Cockpit of the Revolution," and "Crossroads of the American Revolution" today. This article uncovers how and why the Continental Army decided to place the bulk of its forces in northern New Jersey for two consecutive winters during the war. Unlike the more renowned Valley Forge winter quarters, neither New Jersey encampment has received significant scholarly attention, and most works that have covered the topic have presumed the state's terrain offered obvious strategic advantages for an army on the defensive. This article offers a new interpretation, emphasizing the army's logistical needs including forage for its animals and timber supplies for constructing winter shelters. The availability of these resources, rather than easily defended rough terrain or close-proximity to friendly civilians, led Washington and his staff to make northern New Jersey its mountain home for much of the war. By highlighting to role of the environment in shaping military strategy, this article adds to our understanding of New Jersey's crucial role in the American struggle for independence.

\section{Introduction}

In early December, 1778, patriot soldiers from Delaware, Maryland, Pennsylvania, and Virginia arrived at the southern foothills of New Jersey's Watchung Mountains and began erecting a log-hut winter encampment near Middlebrook. Through the following June, the Middlebrook encampment housed some 6,000 men, making it the largest concentration of troops in General 
George Washington's Continental Army that winter. From December 1779 to June 1780, Washington quartered an even larger 10,000-man force ten miles north of Middlebrook at Jockey Hollow near Morristown. Through 1781 and 1782, smaller Continental units also wintered in the vicinity of Morristown. The hills and forests of Morris and Somerset Counties thereby hosted the majority of the Continental Main Army through much of the second half of the War of Independence, one of the state's key contributions to the Revolution.

Unlike the more renowned 1777-1778 winter encampment at Valley Forge, scholars have devoted little attention to the decision-making process that led the Continental Army to establish its cantonments at Middlebrook and Morristown. A handful of studies of the encampments have presumed the defensive advantages of northern New Jersey's terrain made the region an obvious choice for quartering the army. For example, the historian of the Middlebrook encampment Carl Prince asserted that "Washington knew the area was easily defensible," while also ensuring the protection of the New Jersey countryside and enjoying the support of a well-affected population. ${ }^{1}$ For Morristown, John T. Cunningham and Samuel Stelle Smith have similarly highlighted the region's defensibility, with the former referring to the Watchung Mountains shielding Morristown as the "Revolution's most formidable natural bulwark." Morris County historian Theodore Thayer also presented northern New Jersey as an "eagle's nest," secure from enemy attack. ${ }^{3}$ Only Leonard Lundin, in his 1940 The Cockpit of Revolution provided a more detailed analysis, highlighting the importance of supply routes to the west and south in shaping patriot strategy in New Jersey. ${ }^{4}$ In the most recent synthetical treatment of New Jersey's place in the war, historian

\footnotetext{
${ }^{1}$ Carl Prince, Middlebrook: The American Eagle's Nest (Somerville, NJ: Somerset Press, 1957), 3.

${ }^{2}$ John T. Cunningham, The Uncertain Revolution: Washington and the Continental Army at Morristown (West Creek, NJ: Down the Shore Publishing, 2007), 13; Samuel Stelle Smith, The Darkest Winter: Morristown, 1780 (Monmouth Beach, NJ: Philip Frenau Press, 1980).

${ }^{3}$ Theodore Thayer, Colonial and Revolutionary Morris County (Morris County Heritage Commission, 1975), iii.

${ }^{4}$ Leonard Lundin The Cockpit of Revolution: The War for Independence in New Jersey (Princeton, NJ: Princeton University Press, 1940), 418.
} 
Mark Lender reinforced the standing interpretation by highlighting the state's secure lines of communication to other regions, locally available supplies, and, most importantly, the "defensive landscapes of northern New Jersey" that made locales such as Morristown ideal for establishing headquarters and winter encampments. ${ }^{5}$

This article seeks to uncover how and why the Continental Army came to make its encampments in northern New Jersey after 1778, by focusing on command-decisions made in the late 1778 and 1779. Through an examination of Continental officers' contemporary writings, this study finds that, in contrast to previous interpretations of the encampments, northern New Jersey's defensive potential did not figure prominently in most patriot generals' suggestions for winter dispositions. Basing their proposals on the criteria of defensibility and secure lines of communication, most of Washington's subordinates found that New York's Hudson Valley, rather than the New Jersey Highlands, offered the best prospects for wintering troops, while the longterm placement of sizeable Continental formations in New Jersey enjoyed only limited support in late 1778. Nevertheless, a small cohort of officers, mostly from the Quartermaster's department, convinced Washington that majority of the Main Army must winter in New Jersey for logistical, rather than defensive purposes. Under Major General Nathanael Greene's leadership, these officers suggested a New Jersey winter encampment to mitigate supply difficulties; with the majority of its food drawn from farms in Pennsylvania and Maryland, a New Jersey base would shorten supply lines significantly compared to one near West Point, the preferred option of most of Washington's subordinates.

At the heart of the quartermaster department's arguments for a New Jersey encampment, and unrecognized in previous scholarship, were keen environmental insights. Greene argued that

\footnotetext{
${ }^{5}$ Mark Lender, “The Cockpit Reconsidered: Revolutionary New Jersey Considered as a Military Theater," in New Jersey in the American Revolution, ed. Barbara Mitnick (New Brunswick, NJ: Rivergate, 2007), 46.
} 
a winter position in the Hudson Valley would lead to excessive forage requirements for the army's animal teams hauling supply wagons long distances from storehouses located near Trenton. Greene estimated New Jersey's grasslands might sustain these teams, but supply problems would likely arise further north as forage grew increasingly scarce in the rough terrain near the Hudson, already exhausted by a summer's campaign in the region. Additionally, close examinations of the landscape found that the rough terrain of the Hudson Highlands could not accommodate the large, concentrated winter encampment Washington envisioned for the winter, while the more open ground near Middlebrook could. These factors combined to make an encampment in northern New Jersey the most attractive option for winter quarters available to the patriot army.

Ultimately, after consulting more than a dozen of his subordinates, Washington opted to position the bulk of his forces at Middlebrook for the 1778-1779 winter, reaching his final decision two months after originally querying his generals. The ensuing success of the Middlebrook encampment validated the selection of a northern New Jersey site for winter quarters, and for 17791780 Continental commanders assumed New Jersey would be their winter destination. New Jersey thereby served as home to up to 10,000 Continentals for two successive winters, providing one of the state's major contributions as the "Cockpit of the Revolution." The decision to winter the Continental Army in New Jersey, rather than New York, derived not from a perceived defensibility of its terrain as most scholars have assumed, but rather due to the abundant forage its grasslands afforded, its proximity not only to the British base at New York, but also to its supply hub at Trenton, and an abundance of locally available timber. Ultimately, logistical feasibility and ease of camp construction trumped defensibility, strategic position, or political concerns in Washington's decision for placing winter quarters.

\section{Strategy, Supplies, and the 1778 Quartering Debate}


The Continental Army engaged in its first strategic debate over the location of its winter quarters during the winter of 1777-1778. After the British capture of Philadelphia in September 1777, the Continental Army eventually established its winter quarters in a "log-hut city" at Valley Forge, Pennsylvania, only after a prolonged deliberation involving Washington's subordinates, members of the Continental Congress, and Pennsylvanian politicians. Balancing the need for a secure site to rest the army, the desire to protect patriot civilians living near occupied-Philadelphia, and the possibility of a winter attack to recover the lost capital, Washington considered campsite suggestions ranging from Wilmington to Reading. Pennsylvania historian Benjamin Newcomb's study of the decision-making process that led Washington to encamp the bulk of his forces at Valley Forge in December 1777 finds that ultimately the Commander-in-Chief opted to winter along the Schuylkill as this site best satisfied the army's military needs, while Valley Forge historian Wayne Bodle emphasizes the state government's role in pressuring Washington to remain close to Philadelphia to safeguard Pennsylvania's Whig inhabitants. Balancing military and civilian interests, Valley Forge proved to be the best option for an army concerned with maintaining discipline and cohesion, harassing its enemy, and denying opposing forces access to the Pennsylvania countryside. ${ }^{6}$

Continental winter strategy outside of New York after 1778 shared similarities with the winter of 1777-1778. Following French intervention, British forces evacuated Philadelphia in June 1778 and relocated their headquarters back to New York City. An indecisive season of raids and maneuvers followed the Battle of Monmouth, and by October, the Continental Main Army held

\footnotetext{
${ }^{6}$ Benjamin Newcomb "Washington's Generals and the Decision to Quarter at Valley Forge," The Pennsylvania Magazine of History and Biography 117 no. 4 (October 1993), 309-329; Wayne Bodle, "Generals and Gentlemen: Pennsylvania Politics and the Decision for Valley Forge," Pennsylvania History: A Journal of Mid-Atlantic Studies 62 no. 1 (Winter 1995), 59-89.
} 
positions in New York's Hudson Valley. The factors that shaped the overall strategic situation in the region would remain little-changed from 1778 through the end of major fighting. A Britishheld port city once again lay at the center of the operational zone, with a large garrison placing the surrounding area under the threat of attack. The patriot stronghold at West Point, New York, stood guard over the Hudson as the river passed through the narrows of the rugged Hudson Highlands and anchored communication routs connecting New England to the Mid-Atlantic region. While rebel forces sought to protect Whig populations in New York, New Jersey, and Connecticut, safeguarding West Point and deterring a British offensive up the Hudson remained the Continentals' primary strategic goal from 1778 to $1781 .^{7}$

With the Continental Army's winter dispositions unresolved in October 1778, and colder weather approaching, Washington sought his subordinates' input regarding where and how the army should establish winter quarters just as he had before Valley Forge. The Commander-inChief issued a circular to seven of his subordinates on October 14, 1778, requesting their opinions on how the army should arrange its forces for the coming winter. He asked first for recommendations for what dispositions the army should take, considering "the security of the army itself--its subsistence and accommodation-protection of the Country--the support of our important posts," potential collaborations with the French fleet should it arrive, as well as cooperation with posts in New England. Above all, Washington wanted to know whether the army should remain concentrated during the winter, or divided into small cantonments, and in what manner and in what place it should locate its encampments. ${ }^{8}$ He supplemented his original circular with a council-ofwar on October 16, once again querying his officers for suggestions regarding winter dispositions.

\footnotetext{
${ }^{7}$ For the changing character of the northern war after 1778, see Mark V. Kwasny, George Washington's Partisan War (Kent, OH: Kent State Press, 1993), 225.

${ }^{8}$ Washington's “Circular to Seven General Officers," October 14, 1778, The Papers of George Washington, W. W. Abbot, et al. (Charlottesville: University of Virginia Press, 1987), Revolutionary War Series, volume 17, 373.
} 
The Commander-in-Chief ultimately received responses from Major Generals William Alexander, Horatio Gates, Nathanael Greene, Johann de Kalb, Alexander McDougall, Israel Putnam; Baron Freidrich von Steuben; and Brigadier Generals James Clinton, Henry Knox, Samuel Holden Parsons, William Maxwell, Peter Muhlenberg, William Smallwood, Anthony Wayne, and William Woodford.

Each respondent weighed multiple considerations: the logistical problems inherent in supplying the army at a suggested encampment site, the likelihood of a British attack, the possibility of French reinforcements, the protection of well-affected civilians, and the defensive benefits of rough terrain. Washington's subordinates remained discordant, however, on several fronts. Estimations of the army's logistical capabilities varied from bullish to pessimistic, as did suppositions regarding Britain's potential for an offensive. The generals' diverse responses revealed the division of opinion over what positions the Main Army should take and whether it should disperse or concentrate for the winter.

The respondents fell into three categories. Smallest in numbers were those Continental leaders opposed entirely to an arrangement of forces placing the army in close proximity to New York. Comprised largely of Northern Department officers, this faction had not experienced the Valley Forge winter encampment. Accustomed to a different strategic environment, this northern clique did not perceive a political or military need to place the army in a concentrated cantonment for the winter. Major General Horatio Gates took a dim view towards a potential British incursion, believing only troops "equal in number to those the enemy may leave in New York" were necessary to cover the Hudson River, the Hudson Highlands, and New Jersey. Gates instead led the faction that endorsed dispersing the army throughout the Middle Colonies to ease its 
subsistence. ${ }^{9}$ Brigadier Generals Enoch Poor and John Paterson, operating under Gates' command, endorsed his views as well. ${ }^{10}$ Similar support for a distended arrangement arose from Brigadier General William Maxwell. The New Jersey native believed that dispersing the army would ease the difficulty of providing supplies and quarters for the men, claiming "they are more likely to obtain better quarters, vegetables, and all other necessaries in small cantonments than in large bodies." Putting forth the most widely-spread arrangement of any of the generals, Maxwell advised cantonments "from the North (Hudson) River to the Susquehanna," placed wherever was "handy to provisions and forage." 11 For all of these commanders, concerns over supplies, no doubt informed by reports of, or in Maxwell's case direct experience with, the shortages witnessed at Valley Forge, overrode defensibility, unit cohesion, or safeguarding civilian communities in the arrangement of forces for the winter. They also believed that forces must disperse to subsist locally, rather than rely upon the insufficient national logistical apparatus.

In contrast to the northern clique, defensibility and cohesion stood out as paramount concerns for the majority of Washington's subordinates. Four brigadier generals who had served in Pennsylvania the previous year (Hand, Muhlenberg, Smallwood, and Wayne) proffered deployments that placed the majority of the army in the Hudson Highlands, with a chain of detachments stretching from Connecticut to New Jersey anchoring either flank. The importance of West Point and the Hudson Highlands, as well as the strategic similarities between the Philadelphia theater a year earlier and the army's current situation, shaped most of the generals' responses. Finally, the potential appearance of a French fleet in the area made a tighter

\footnotetext{
${ }^{9}$ Gates to Washington, October 19, 1779, PGW, Revolutionary War Series, Volume 17, 460-461.

${ }^{10}$ Gates to Washington, October 19, 1779, PGW, Revolutionary War Series, Volume 17, 460-461.

${ }^{11}$ William Maxwell to Washington, October 21, 1778, PGW, Revolutionary War Series, Volume 17, 506-511.
} 
arrangement of forces attractive, as this would ease the task of concentrating the army for a potential attack on New York.

The majority of those surveyed outlined broadly similar plans for the winter, all placing emphasis on the Hudson River near Fishkill. Muhlenberg, for example, stressed the two "Grand Objects," of cooperating with the French fleet and guarding the passages through the Hudson Highlands. He favored a limited dispersal of forces, keeping the brigades close enough that "the whole might be able to join in three or four days if it should be found necessary." He suggested the largest portion of the army remain at Fishkill on the Hudson, "a very secure post," at which the mountainous terrain of the Hudson Highlands would impede any British advance, while smaller brigade-sized detachments would guard New Jersey and Connecticut. ${ }^{12}$ Wayne responded with similar sentiments, telling Washington he was "solemnly opposed to a division of your Army into cantonments-the dangerous consequences attending such a measure are too obvious to require any comment." Wayne repeated the refrain of the need to protect the Hudson, and suggested Kings Ferry as a possible site. In a departure from other respondents, the Pennsylvanian recognized that environmental factors, such as access to fresh water and timber, would dictate where to camp. If such items could not be found at Kings Ferry, he recommended a post between there and Fishkill. Revealing his perception of New Jersey's lack of strategic importance, Wayne advised sending only a single brigade to winter in that state. ${ }^{13}$ Brigadier Samuel Holden Parsons' proposal likewise placed the majority of the army near Fishkill, with smaller detachments covering West Point and Smith's Clove along the Hudson, as well as Danbury in Connecticut. ${ }^{14}$ William Smallwood and

\footnotetext{
${ }_{12}$ Muhlenberg to Washington, October 16, 1778, PGW, Revolutionary War Series, Volume 17, 408-409.

${ }^{13}$ Wayne to Washington, October 18, 1778 PGW, Revolutionary War Series, Volume 17, 452-453.

${ }^{14}$ Parsons to Washington, October 17, 1778, PGW, Revolutionary War Series, Volume 17, 424-425.
} 
Edward Hand expressed similar sentiments while admitting to a lack of local geographic knowledge to offer more than a general outline for arrangements. ${ }^{15}$

The Continental Army's European officers offered more thoroughly articulated plans for winter quarters than many of the brigadiers, but mostly shared the latter's emphasis on the Hudson Highlands. Major General von Steuben respected the power of the British forces remaining in New York, and argued against a dispersal of forces, writing that "to scatter our forces with a view of protecting all points, will put it out of our power to protect any--and we shall run the risk of being beat in detail." Von Steuben also opposed shifting the main body of forces to Connecticut or New Jersey at the expense of uncovering the Hudson. He proffered the most concentrated arrangement of any of Washington's subordinates, with thirteen brigades remaining along the Hudson, three in Connecticut at Danbury, and only a small force of infantry under Lord Stirling to cover New Jersey, supported by the light cavalry and militia. ${ }^{16}$ Johann de Kalb, echoed von Steuben's preference for a concentration of force along the Hudson, proposing to send only a single brigade to Elizabethtown in New Jersey and no forces to Connecticut. Instead, de Kalb's plan called for an even divide between the eastern and western sides of the Hudson, believing the river's freezing would permit close coordination between the two wings during the winter. A similar plan arose from Brigadier General John Nixon, who criticized the logistical feasibility of a concentrated deployment on the Hudson; like de Kalb, he suggested dividing the army into two "grand Divisions," on either side of the Hudson, easing logistical difficulties and covering more ground. ${ }^{17}$

\footnotetext{
${ }^{15}$ Smallwood to Washington, October 17, 1778, PGW, Revolutionary War Series, Volume 17, 428-429; Hand to Washington, October 18, 1779; Ibid., 439-440.

16 Von Steuben to Washington, October 18, 1779, PGW, Revolutionary War Series, Volume 17, 450; de Kalb to Washington, October 19, 1779; Ibid., 463-465.

${ }^{17}$ Brigadier General John Nixon to George Washington, October 19,1778, PGW, Revolutionary War Series, Volume 17, 468-469.
} 
Three of Washington's most experienced commanders, Brigadier General Henry Knox and Major Generals Lord Stirling and Nathanael Greene, dissented from the consensus strategy and offered detailed alternative plans. Each provided similar justifications for their opposition to a concentration in the Hudson Highlands, first that the region's rough terrain made possible its defense by a small force, and second that the area lacked the forage needed for Continental supply trains. Knox preferred sending the bulk of the army to Connecticut to secure that state's defenses and facilitate the army's supply. He recognized the logistical problems that a concentration entailed, but believed by taking "a proper position," these issues could be alleviated and suggested the area between Ridgefield Connecticut and Crompond New York for a winter encampment, further east than the Peekskill-Fishkill-West Point region that the majority of respondents advocated.

More clearly than most of his peers, Knox articulated the logistics of his proposed site, suggesting Danbury, Connecticut, Fishkill, New York, and "some place immediately in the rear of the army," as locales for the erection of magazines to succor the winter encampment. Knox recognized that many foodstuffs would arrive from the south and west, and highlighted "the goodness of the roads below the mountains through the Jersies," as a crucial line of communications. Describing northern New Jersey as a "country abounding with forage," Knox felt supply trains routed through the state would have little difficulty sustaining an army concentrated in eastern Connecticut, while in regards to the supplies needed to erect a winter encampment, he stood "confident," that a position featuring sufficient timber and suitable ground for a cantonment "might be found near Ridgefield."18

${ }^{18}$ Ibid. 
Logistical concerns also featured prominently in Lord Stirling's proposal. The Rebel Earl asserted that a concentrated encampment in the Hudson Highlands would be difficult to provision. Unlike Knox, Stirling suggested the army should winter west of the Hudson, as he believed that based on "the state of cartage $\&$ forage... it is absolutely impractical to maintain the army in flower \& grain in any situation on the east side of Hudson's River." In an inversion of Knox's arrangements, Stirling's plan placed "three or four" brigades on the left wing in Connecticut, with only a single brigade to guard West Point and the Hudson Highlands, with the remainder of the army to canton in New Jersey towns dispersed from Hackensack to Burlington to ease its subsistence. The units that the towns could not accommodate would encamp "at the foot of the mountain at Scotch Plains or Middlebrook." Stores would be sent to a "very safe" position behind the Watchungs, either Morristown or Pluckemin. ${ }^{19}$ Stirling's proposal thereby recognized the defensive potential of northern New Jersey's terrain, albeit only for supply depots as his suggested arrangement placed the troops' cantonments on exposed ground east of the Watchungs.

The clearest understanding of the Continental Army's logistical problems arose from Quartermaster-General Nathanael Greene. Greene wrote to Washington in October 1778 to outline the army's prospects for the winter, distinguishing between the options of a concentrated encampment, as at Valley Forge, or a dispersal of forces. The former promised stronger defensibility, improved discipline, and streamlined foraging; echoing Knox's suggestions, Greene therefore favored, in theory, a "plan for holding the army in a collected state on (the east) side of the North (Hudson) River." ${ }^{20}$ He realized, however, in contrast to Knox, that since forces in Boston and Rhode Island would also draw upon supplies available in New England, while forage from the

\footnotetext{
${ }^{19}$ Stirling to Washington, October 26, 1778, in PGW, Revolutionary War Series, Volume 17, 592-593; Paul David Nelson, The Life of William Alexander, Lord Stirling (Tuscaloosa AL: University of Alabama Press, 1987 ), 137.

${ }^{20}$ Greene to Washington, October 08, 1778, Richard K. Showman ed., The Papers of General Nathanael Greene (Chapel Hill, NC: The University of North Carolina Press, 1989), Volume 3, 4.
} 
Middle States would have to cross the Hudson, an encampment in western Connecticut could not logistically sustain the army. Furthermore, a winter post east of the Hudson invited a British attack up the river that could cut off the Continentals from their mid-Atlantic sources of supply. Consequently, Greene suggested leaving smaller garrisons near West Point and in Connecticut, while shifting the bulk of the army to northern New Jersey, closer to its breadbasket.

Within New Jersey, Greene proffered two options for winter dispositions: one in Bergen County near New York City, and the other further removed in the vicinity of Middlebrook, in the Raritan Valley, where the army had concentrated in the spring of $1777 .^{21}$ Neither of these suggested sites made use of northern New Jersey's purported defensive terrain; they presented attractive locales due the former's proximity to West Point and the latter's position closer to Trenton. Between these two choices, Greene favored a return to the Middlebrook site over making a new encampment in Bergen County. While a Bergen encampment would allow closer coordination with the detachments at West Pont and Danbury, it would also increase the strain on the army's logistical tail that stretched westward to Pennsylvania. Middlebrook lay closer to sources of forage, and the local landscape appealed to Greene; he described the region as "plentiful country, naturally strong and difficult to access and surrounded with a great plenty of wood."22 The latter article was particularly necessary for an army envisioning the construction of log huts for winter shelter, as it had done a year earlier at Valley Forge.

In Greene's formulation for winter quarters, logistical concerns trumped defensibility. Compared to provision and forage, he asserted to Washington that other considerations remained "inferior evils," which "may in some sort be remedied, by foresight and precaution; but there is no

\footnotetext{
${ }^{21}$ For the 1777 Middlebrook encampment, see Lundin, Cockpit of Revolution, 390.

22 Ibid.
} 
contending with hunger." ${ }^{23}$ Greene similarly articulated his justifications for his dispositions to New York Major General Alexander McDougall, claiming “an active vigilant general can guard against every kind of evil but that of want of provision and forage." ${ }^{\text {"24 }}$ Greene's subordinates in the quartermaster's department reinforced their superior's logistical concerns. In early November 1778, Washington had ordered deputy quartermaster Colonel Clement Biddle to study the logistical feasibility of an offensive against New York. In his response, Biddle described the state of the army's forage in regards to whether it could sustain a potential offensive. He declared that the 12,000 men then under arms would need "to be fed with provisions transported at a great distance. The teams requisite for this purpose will consume a great quantity of forage." To maintain the army's supplies, he estimated "upwards of 5,000 horses to be fed that are necessary to move the army." Additional animal teams conducting routine camp activities also drew forage. Biddle did not believe forage existed in great enough quantities to sustain such an operation, declaring "it may be attended with destructive consequences," to entertain an offensive against New York without proper forage supplies. ${ }^{25}$

In Biddle's estimation, New Jersey could barely sustain the Main Army in its current position on the Hudson, and the army's animal teams' forage needs bore responsibility for this distress. Throughout the late summer and fall, teams had hauled supplies from the south and west through New Jersey to the Hudson Highlands, and in their passing through the state, these teams consumed local forage stocks. By late 1778, teams further tapped into army supplies by consuming stores drawn from nearby states. According to Biddle, a "great part of the grain which was consumed by teams in that state (New Jersey) was brought from Pennsylvania and the southern

\footnotetext{
${ }^{23}$ Greene to Washington, November 14, 1779, GP Volume 4, 264-65.

${ }^{24}$ Greene to McDougall, November 8, 1778, GP Volume 3, 48.

${ }^{25}$ Clement Biddle to Greene, November 19, 1778, GP Volume 3, 76.
} 
states to Trenton." Winter ice promised to suspend transport on the Delaware, meaning few provisions at Trenton would be restocked prior to the army's entering into winter quarters. Concentrating the bulk of the army for an offensive against New York, or a winter encampment, would, in Biddle's view, most likely exhaust forage supplies and render the army immobile and in danger of famine. ${ }^{26}$

Other members of the quartermaster's department expressed even greater pessimism. Deputy quartermaster James Burnside lamented that teams passing from Pennsylvania to the Main Army's position on the Hudson could go no further than his post at Morristown for there was "no forage to carry them on" to King's Ferry and Fishkill. ${ }^{27}$ Writing in early November, when a Hudson Highlands encampment appeared most likely, Burnside outlined a proposal for supplying a northern site, with teams passing from New Brunswick to Springfield, Aquanckononck, ${ }^{28}$ and on to Kings Ferry, a route that would leave the army's horse teams "better supplied with hay and pasture." 29 Teams passing through the region along a more westerly and secure route through Morristown suffered from a lack of forage, forcing Burnside to halt several trains at Morristown as the scarcity and expense of forage in Morris County prohibited their passage further north. ${ }^{30}$ Burnside claimed that the shortages that immobilized teams passing through Morristown did not arise from natural deficiencies, but an inability to purchase hay, flower, and Indian corn at the prices New Jersey farmers demanded. Describing the forage scarcity as "artificial," he believed supplies could be "had all winter," provided the quartermaster's department could purchase the

\footnotetext{
${ }^{26}$ Clement Biddle to Greene, November 19, 1778, GP Volume 3, 77.

27 James Burnside to Major Peter Gordon, November 8, 1779, James Burnside Letterbook, Historical Society of Pennsylvania (HSP).

${ }^{28}$ Near present-day Paterson.

${ }^{29}$ James Burnside to Major Peter Gordon, November 8, 1779, James Burnside Letterbook, HSP.

${ }^{30}$ Burnside to Moore Furman, November 13, 1778, Burnside Letterbook, HSP.
} 
article in sufficient quantities. In early November however, New Jersey farmers appeared “determined to keep ahead of us." "31

Whether the army had actually depleted the available forage supply, as Biddle argued, or simply lacked the finances to purchase the article, as Burnside contended, forage promised to remain scarce through the 1778-1779 winter. These considerations led Greene to suggest Middlebrook, rather than a more northerly encampment in Bergen County, for the 1778-1779 winter. Highlighting the importance of animals to the army's arrangement, Greene noted a Bergen County encampment would mean "all the forage upon the upper and lower communication will be wanted for the cattle employed in transporting stores eastward." Teams victualing a Bergen County position, forty miles further from Trenton than Middlebrook, would consume a substantially greater amount of forage. ${ }^{32}$ New England's inability to sustain local forces and a recent crop failure in New Jersey necessitated food supplies be shipped to the region from further afield. The quartermaster's department estimated 500 horse teams as the minimum needed to feed the army on the Hudson; since this added distance would necessitate great consumption of forage, the army would then require an additional 134 teams to sustain these. Overall, Greene's staff calculated the total number of teams needed to victual the army itself, if it encamped along the Hudson, the additional teams to haul forage for the primary teams, and other teams needed to carry-out ancillary duties, at 1,474 (or 5,896 horses). These estimates presupposed that New Jersey's local forage stocks would be completely consumed, leaving the army entirely dependent on forage transported from elsewhere. ${ }^{33}$

\footnotetext{
${ }^{31}$ Burnside to Charles Stewart, November 15, 1778, Burnside Letterbook, HSP.

${ }^{32}$ Greene to Washington, October 18, 1778, GP Volume 3, 3.

${ }^{33}$ Estimation of Teams Required to transport Provisions and Forage from Trenton to Kings Ferry, October 1778, GP Volume 3, 19-20.
} 
The Main Army's situation in late 1778 resembled that of a modern army operating at a distance from its railhead. Late-industrial armies reliant upon automotive transportation at times found themselves operating at such great distance from rail or water-born supply hubs that additional trucks were needed to refuel those hauling gasoline, food, and ammunition to frontline forces, greatly complicating the logistical situation. Similarly, the Continental Army, operating in the context of water and animal transport of the agrarian age, relied upon the forage readily afforded by the surrounding environment. Placing substantial forces further from its supply hub at Trenton significantly increased the consumption of available forage. Under the constraints of the natural world, the Continental Army could only ensure consistent supplies by encamping as close as possible to the Delaware River, while remaining within New York's operational sphere. ${ }^{34}$

\section{Selecting Encampment Sites}

Environmental considerations played a further part in determining New Jersey's role as a winter home for the army by shaping where the Continentals could most easily erect their quarters. With a general arrangement of forces decided upon by late November, Washington and his subordinates turned to the problem of where to build the encampments that were to anchor the Continentals' winter dispositions. By December 1778, rebel officers had adopted the log-hut city form of encampment, erecting hundreds of simple wooden shelters across the landscape. Easy access to food, water, and timber for fuel and construction, as well as suitable defensive ground, shaped the selection of encampment sites. Terrain thereby played a crucial role in this search, as did environmental features including forests, farms, and watercourses. ${ }^{35}$

\footnotetext{
${ }^{34}$ For the logistical problems of twentieth-century armies, see Martin van Creveld, Supplying War: Logistics from Wallenstein to Patton (New York: Cambridge University Press, 1977), 203-230.

${ }^{35}$ For the importance of wood and water earlier in the war, see David C. Hsiung, "Food, Fuel, and the New England Environment in the War for Independence, 1775-1776," The New England Quarterly, 60, no. 4 (2007): 614-54; for forests' impact on warfare throughout military history, see John R. McNeill, "Woods and Warfare in World History," Environmental History 9, no. 3 (2004): 388-410.
} 
During the autumn of 1778 , the quartermaster's department turned its attention to finding a site suitable to cantoning large portions of the Main Army. Availability of timber, dry ground, fresh water, and enough open space for hut sites and parade grounds guided this hunt for encampment sites. Early searches in the Hudson Highlands revealed the difficulty of meeting these criteria while also remaining in defensible terrain and close to supplies. Greene and Major General Israel Putnam surveyed the ground in the vicinity of Kings Ferry, New York, and found "but one tract of woodland of sufficient extent to hut the army collectively." 36 The rough country around Fishkill promised to break-up the encampments into individual brigades, and there was no ground upon which the army could exercise or maneuver. Mostly divided into small farms, the region lacked substantial woodlots beyond those small holdings of the individual farmers. According to Greene, if the soldiers encamped along the Hudson, "their situation in the Highlands will be little better than in a gaol." 37 The region's environmental unsuitability for an encampment, as well as Greene's reservations about provisioning the Main Army east of the Hudson, induced him to recommend a shift to New Jersey for winter quarters. Indeed, from 1778 through 1780, only small detachments wintered in the Hudson Highlands.

Middlebrook, by contrast, lay close to sources of forage, and enjoyed favorable local environmental conditions, easing the decision to quarter the bulk of the Main Army along the Raritan in late 1778. Greene wrote to Washington on November 30 that he planned to "fix upon a place for hutting," as soon as rainy weather improved to allow his travel. ${ }^{38}$ By early December, the quartermaster put forth two prospective encampment sites in the vicinity of Middlebrook, of which Washington could not determine which was best "without seeing them." ${ }^{39}$ Two days later

\footnotetext{
${ }^{36}$ Greene to Washington, October 24, 1778, GP Volume 3, 13.

37 Ibid.

${ }^{38}$ Greene to Washington, November 30, 1778, GP, Volume 3, 91.

${ }^{39}$ Robert H. Harrison to Greene, December 5, 1778, GP, Volume 3, 105.
} 
Washington decided upon "the situation marked out in the first instance." 40 Greene described the site as "directly back of Bound Brook below the mountain." 41 Familiar with the region after the Army's brief presence there in early 1777, the Rhode Islander favored a position in Somerset County due to its agreeable environment. With the Watchung Mountains at its back, Middlebrook was, according to Greene, "situated in a plentiful country, naturally strong and difficult of access and surrounded with a great plenty of wood." 42 Indeed, the nearby Raritan Valley had served as an important pre-war source of timber for New York, and consequently was home to ample supplies of wood. ${ }^{43}$ A contemporary newspaper advertisement described the countryside near the Virginia division's encampment as "most-excellent timberland," while the vicinity of the artillery park at nearby Pluckemin featured 8,000 acres of timberland. ${ }^{44}$ Given this abundant timber supply, the defensive potential of the local hills, and proximity to supply lines, selecting a specific encampment site within the vicinity of Middlebrook proved a straightforward task, as Washington and Greene apparently agreed upon a place for hutting within a few days in early December 1778.

\section{Civilian Considerations and the Military Response}

In contrast to the Valley Forge winter, plans for the Continental Army's arrangement around New York in late 1778 received little input from civilian leaders. While congressional delegates voiced to Washington their concerns over the southern theater and expressed interest in an operation against Canada, they deferred to Washington's authority on the matter of winter quarters. The strongest requests for adjustments to Continental dispositions arose from the New Jersey state government, however, these mostly met with Washington's rejection. New Jersey did

\footnotetext{
40 Ibid.

${ }^{41}$ Greene to Moore Furman, December 2, 1778, GP, Volume 3, 94-95.

${ }^{42}$ Greene to Washington, October 18, 1778 GP, Volume 3, 5.

${ }^{43}$ Paul G. Clemens and Peter O. Wacker, Land Use in Early New Jersey: a Historical Geography (Newark NJ: New Jersey Historical Society, 1995), 40-45.

${ }^{44}$ New Jersey Gazette, October 20, 1779.
} 
not lay under partial occupation, as Pennsylvania had a year earlier, allowing Continental leaders to dismiss inhabitants' concerns more easily than they had at Valley Forge. Overall, the deployment of patriot forces for the 1778-1779 winter overwhelmingly derived from military, rather than civilian criteria.

Congressional correspondence with Washington's command during the critical SeptemberNovember 1778 period reveals the civilian leadership's attention towards broader strategic concerns that transcended operations around New York. In late October, as Washington and his subordinates continued to deliberate where the army should winter, the congressional Committee for Foreign Affairs tasked the commander-in-chief with planning an invasion of Canada. ${ }^{45}$ Congress's vision for the attack necessitated substantial detachments from the Main Army be sent to western Pennsylvania and northern New York, with additional recruits to be gathered in northern New England. ${ }^{46}$ Washington opposed the planned offensive, believing he lacked the manpower to effectively cover New York and make a strong contribution to a Canadian invasion, while privately admitting to Henry Laurens that he feared a successful expedition might lead to an unwelcomed resurrection of a French possession on the United States' northern border. ${ }^{47}$ Washington's opposition and Laurens' own suspicions led to an abandonment of the plan by early January $1779 .{ }^{48}$ In retrospect, Congress's envisioning of such a bold undertaking had derived, in John Jay's words, from an expected "speedy \& total evacuation of the posts" British forces held

\footnotetext{
${ }^{45}$ Congressional Committee on Foreign Affairs to Washington, October 27, 1778, PGW, Revolutionary War Series, Volume 17, 597-598; Journals of the Continental Congress, Volume XII (Washington: Government Printing Office, 1908), 1052-1053.

46 Journals of the Continental Congress, Volume XII, 1042-1048.

47 Washington to The President of Congress, November 11, 1778, Fitzpatrick Volume 13, 223-244; Washington to Henry Laurens, November 14, 1778, Ibid., 254-257.

${ }^{48}$ Henry Laurens to Washington, November 20, 1779, Letters of the Delegates of Congress, Volume 11, 229-30.
} 
in the New York area. ${ }^{49}$ When this eventuality failed to occur, less ambitious visions for the 1779 campaign took hold, eventually finding expressions in Sullivan's expedition against the Iroquois. ${ }^{50}$

Congress's focus on such a large strategic venture stood in contrast to lack of interest in the Main Army's winter dispositions. Ultimately only one civilian, Gouverneur Morris, proffered a plan for winter quarters to Washington. Despite his outsider status, Morris outlined an arrangement of forces that aligned with the distended dispositions put forth by the Continental veterans Gates and Maxwell. Attuned to the difficulty of supplying the army when concentrated, Morris suggested spreading the army from Connecticut through New York and northern New Jersey, as well as making detachments to southern New Jersey at Burlington and the re-use of the Valley Forge encampment site. Surprisingly for a civilian leader, Morris also displayed the most explicitly cynical attitude towards protecting civilian communities, declaring that rather than place Continentals in a vulnerable position, he would expose Bergen and Westchester Counties, preferring to "lay them waste by way of saving money." 51 Whatever merits Morris's plan may have held, his suggestions went unheeded.

While Congress deferred to the generals' authority in selecting winter quarters, civilian leaders did make multiple requests to Washington for troops to guard patriot communities. These requests from both national and state leaders forced Washington to contend with the complications brought on by the decision to winter the army along the Raritan. Although the selection of Middlebrook promised to ease the army's logistical plight, the location invited strategic problems. Because the cantonment itself lay at the base of the Watchung Mountains on the outskirts of the

\footnotetext{
49 John Jay to Lafayette, January 3, 1779, Paul H. Smith ed., Letters of the Delegates of Congress, Volume 11 (Washington: Library of Congress, 1985), 408-409.

${ }^{50}$ See Joseph R. Fischer, A Well-Executed Failure: The Sullivan Campaign against the Iroquois, July-September 1779 (Columbia, SC: University of South Carolina Press, 1997).

${ }^{51}$ Gouverneur Morris to Washington, November 11, 1778, PGW, Revolutionary War Series, Volume 17, $253-255$.
} 
New Jersey Highlands, it lacked the inherent defensibility of the Hudson Highlands to the north. To maintain a secure position, as well as to streamline training and discipline, the army could not send substantial detachments to non-critical locations. Washington therefore denied Congressional requests for reinforcements in Philadelphia due to this perceived need for men to secure his position in New Jersey, claiming he could not spare more men, "without leaving this cantonment in so weak a state as to be liable to an insult during the winter." 52

New Jersey’s citizens also felt the need for protection in the fall of 1778 . On October 12, New Jersey governor William Livingston wrote to Stirling requesting detachments be sent to New Brunswick, where "the inhabitants of this city are extremely anxious to have a guard placed here."53 Livingston similarly pressed Washington on November 7 on behalf of Bergen County. Considering "that a part of the army is expected to winter in this state," Livingston and the New Jersey Executive Council felt confident Washington would honor their request to "station a significant number" of Continentals in the threatened county. The governor nevertheless deferred to the general's authority, making clear that he preferred patriot regulars winter in Bergen County only if this arrangement did "not interfere with the plan you may think necessary to adopt for posting your troops in this state." ${ }^{, 54}$ Washington responded on November 18 outlining his arrangement of forces around New York; while the North Carolina Brigade would provide some security at Paramus, the Commander-in-Chief made clear that lower Bergen County "must from its situation remain exposed to the enemy." "55 Already delicately balancing his army's defensive

\footnotetext{
${ }^{52}$ Washington to the Board of War, December 20, 1778, John C. Fitzpatrick, The Writings of George Washington from the Original Manuscript Sources, 1745-1799; Prepared under the Direction of the United States George Washington Bicentennial Commission and Published by Authority of Congress (Washington DC: US Government Printing Office, 1931-1954), volume 13, 437-438.

${ }^{53}$ Livingston to Stirling, October 12, 1778; Carl E. Prince and Dennis P. Ryan ed., The Papers of William Livingston Volume 2 (Trenton, NJ: New Jersey Historical Commission, 1980), 462-463.

${ }^{54}$ Livingston to Washington, November 7, 1778, Livingston Papers Volume 2, 474-475.

55 Washington to Livingston, November 24, 1778, Livingston Papers Volume 2, 490.
} 
and logistical needs, Washington refused to let civilian concerns further weaken his arrangement of troops.

Nevertheless, the New Jersey governor attempted to wrench Continentals from Washington once more the following month, this time for Monmouth County. Writing on December 14, the governor expressed his opinion that "a few Continental troops might be posted in that county to great advantage." Not only would a Continental detachment aid the "loyal citizens" in suppressing Monmouth's active loyalist population, but also interrupt trade with New York and ease subsistence. Cavalry in particular, Livingston felt, would "be better accommodated in those parts than almost anywhere else." 56 In a follow-up letter on December $15^{\text {th }}$, Livingston clarified his plan for Monmouth County and reiterated his request, attaching a petition from the county's Whig residents in support. With the local militia "worn out \& dispirited," Livingston wanted 400 Continentals detached to Middletown, Middletown Point, and Shrewsbury to shoreup the local population and restrict illicit trade with New York. ${ }^{57}$ As he had in his November letter regarding Bergen County, the New Jersey governor deferred to Washington, reiterating that a detachment should winter in Monmouth County only if this fit with the Commander-in-Chief's overall plan.

Washington, despite these repeated urgings, again rejected Livingston's requests for aid. While sympathizing with the governor's concerns for protecting patriot communities and hindering illicit trade, the Commander-in-Chief found he could make no detachment to Monmouth under his plan of cantonment. Although Monmouth County possessed attractive pastures for the cavalry, the Continental dragoons had already gone into quarters elsewhere by mid-December, and the prospect of a winter of active partisan-fighting in coastal New Jersey promised to wear down

\footnotetext{
${ }^{56}$ Livingston to Washington, December 14, 1778, Livingston Papers Volume 2, 510.

${ }^{57}$ Livingston to Washington, December 15, 1778, Livingston Papers Volume 2, 512.
} 
the patriot troopers whose "absolute rest from ordinary fatigue is indispensible," to the following campaign. As for the infantry, considering the majority of the Main Army planned to winter in New Jersey, Washington claimed "the safety of its inhabitants has been a particular consideration," in his distribution of forces. It remained, however "impossible to include every place." Beyond the North Carolina Brigade at Paramus and Maxwell's New Jerseyans at Elizabethtown, Washington remained unwilling to further break up his cantonments. "Should I venture on any further detachments from this part of the army," he argued, "it might very much endanger the whole." In addition to endangering the army's supply stores, small, isolated cantonments might find themselves vulnerable to sudden British attack, to which a reduced main body of Continentals would be powerless to "give any essential service to the state at large or a serious opposition to the enemy." ${ }^{58}$ Livingston accepted Washington's judgment without protest. ${ }^{59}$

For purposes of supply and security, Washington had already broken the Main Army into smaller detachments than he had in southeastern Pennsylvania. The forces posted to the Hudson Highlands, however, enjoyed the protection of the local rough terrain, while those in Connecticut stood at the furthest distance from New York. Both the North Carolina Brigade at Paramus and the New Jerseyans at Elizabethown could fall back to more defensible positions if threatened, or await reinforcements from Middlebrook. Troops sent to lower Bergen County, or split amongst various Monmouth County towns, appeared too isolated and vulnerable in Washington's estimation at the outset of the winter encampment. Nevertheless, as the winter progressed he softened his stance and agreed to post a lone Pennsylvania regiment to Monmouth County to suppress trade with New York. ${ }^{60}$ This additional protection covered the New Jersey countryside

\footnotetext{
${ }^{58}$ Washington to Livingston, December 16, 1778, Livingston Papers Volume 2, 513-514.

${ }^{59}$ Livingston to Washington, December 21, 1778, Livingston Papers Volume 2, 518.

${ }^{60}$ Livingston to Washington, February 8, 1778, Livingston Papers Volume 3, 34.
} 
until early May, when Washington withdrew both the Pennsylvania detachment from Monmouth and Maxwell's brigade from Elizabethtown in preparation for Sullivan's campaign against the Iroquois. $^{61}$

Washington's prolonged resistance to making even this small detachment of 400 men available to guard Monmouth County revealed the uncertainty surrounding the strategic situation around New York in late 1778. For only the second time, a large, long-service Continental Army embarked on the tasks of building winter quarters and preparing for a war of posts. The potential threat of the British garrison in New York and the possible arrival of the French fleet added new complications, while the supply shortages and implementation of better training that had characterized the Valley Forge winter remained present. In such a strategic environment, politicians' calls for an invasion of Canada found little enthusiasm at Main Army headquarters, and requests for detachments to safeguard the capital or threatened civilian communities met with frequent rejections.

With military concerns' primacy asserted over those of civilian leaders, Washington's plan for the winter of 1778-79 ultimately incorporated elements of Stirling's, Knox's, and Greene's suggestions, though it bore the closest resemblance to the latter's plan. To satisfy West Point's defensive requirements, three Massachusetts brigades encamped in the New York Highlands. Numbering 3,100 men, including militia detachments, the Massachusetts brigades did not invite the logistical problems Greene believed encamping the whole army at West Point would have entailed, nor did the small Massachusetts units need as much open ground upon which to situate a camp. The North Carolina Brigade cantoned at Smith's Clove in support of West Point; together these units secured the passes into the Hudson Highlands. Two Connecticut and one New

\footnotetext{
${ }^{61}$ Washington to Livingston, March 4, 1779, Livingston Papers Volume 3, 68.
} 
Hampshire brigade under General Putnam quartered near Reading, Connecticut to shore-up defenses in that state. Putnam's wing thereby fulfilled the suggestions of several of Washington's subordinates, most prominently Knox, to place substantial forces east of the Hudson. Reflecting a blend of Greene's and Stirling's proposals, seven brigades from Virginia, Maryland, Delaware, and Pennsylvania constituted the main encampment at Middlebrook, at the foot of the Watchung Mountains in New Jersey, with the artillery at nearby Pluckemin. Concern for the army's lines of communications with West Point led to the North Carolina Brigade's redeployment to Paramus, New Jersey, while a mixed brigade under Edward Hand garrisoned Minisink near the New YorkNew Jersey border. The limited availability of fodder for the army's vital supply trains necessitated the cavalry's dispersion, with regiments detached as far as Winchester Virginia, Lancaster Pennsylvania, and Derham Connecticut. Only Lee's unit remained near the Main Army, wintering in southern New Jersey. ${ }^{62}$ Political concerns also played a role, with the New Jersey Brigade guarding the state's border with New York at Elizabethtown, but aside from the single regiment sent to Monmouth County in February, Washington approved of no detachments to guard threatened Whig communities or suppress loyalists. ${ }^{63}$

Washington articulated his reasoning for his dispositions as a balance of logistical and strategic concerns. His concentrations guarded the key routs into the Hudson Highlands and afforded the troops safety from British attack. The distribution of forces promised ease of supply and less of a burden on local civilians. Justifying his dispositions to Congress, Washington claimed "to have kept the troops in a collected state would have increased infinitely the expense

\footnotetext{
${ }^{62}$ Washington to Congress, November 27, 1778; in Fitzpatrick, Volume 13, 350-52; Washington to Greene, December 4, 1778, GP Volume 3, 32; Charles Lesser, Sinews of Independence, Monthly Strength Reports of the Continental Army (Chicago: University of Chicago Press, 1976), 100-101.

${ }^{63}$ Lesser, Sinews, 100-101.
} 
and difficulty of subsisting them...to have divided them into smaller cantonments, would have made it far less practicable to maintain order and discipline among them." Further dispersal would have also constrained his ability to contest a British advance, or to concentrate to launch his own attack should the opportunity arise. ${ }^{64}$ The route up the Hudson remained the Continentals' defensive priority, but the Hudson Valley lay at too great a distance from the army's primary supply sources to make for a viable winter position for the majority of the force.

\section{Conclusion: The Morristown Winter and After}

In contrast to the army's experience at Valley Forge, the Continentals spent the winter at Middlebrook with comparatively few difficulties. Two Virginia and two Maryland brigades erected quarters secure in the Watchung foothills, taking advantage of abundant local timber supplies, while the late-arriving Pennsylvanians encamped south of the Raritan on wet ground that proved less satisfactory. Overall, the Continentals in New Jersey faced fewer supply difficulties and enjoyed better security than they had experienced the previous winter. As the Main Army broke camp in June 1779, Brigadier General William Irvine highlighted the newly-realized strategic benefits of posting the army in northern New Jersey. He described a position near Morristown as "the most advantageous situation should it not be thought proper to act offensively." Among New Jersey's attractive qualities for wintering troops, Irvine listed "healthy country," convenient access to "supplies from every quarter," a central position from which to counter a potential British thrust to the south, as well as strong defensive ground "inferior to none." Considering northern New Jersey's superior logistical sustainability and access to vital camp supplies, Irvine, in his comparison, placed the region above even New York's Hudson Highlands in regards to defensibility and overall attractiveness as defensive ground for the army. ${ }^{65}$

\footnotetext{
${ }^{64}$ Washington to Congress, November 27, 1778; in Fitzpatrick, Volume 13, 350-52.

${ }^{65}$ Irvine to Washington, May 28, 1779, PGW, Revolutionary War Series, Volume 20, 660-661.
} 
The success of the Middlebrook encampment elevated northern New Jersey as the preferred option for cantoning the army the following winter. Broadly, the strategic pattern remained unchanged through 1780 with winter dispositions once again encircling New York; however, uncertainty over British intentions following their buildup in the city led Washington to seek a more geographically secure location. Unlike the previous winter, no grand debate over where to place the bulk of the army ensued. The Commander-in-Chief's initial plans for winter quarters looked once more to the Watchungs, envisioning an encampment in the vicinity of the Quibbletown Gap that would essentially parallel the advantages of the Middlebrook encampment from the previous year. In contrast to 1778-1779, however, a buildup of British forces in New York necessitated a more secure encampment than either Middlebrook or Quibbletown promised. Declining manpower thereby induced Washington to shift away from the dispersed deployments of 1778-1779 and instead concentrate his forces in a few compact cantonments in northern New Jersey and the Hudson Valley. By mid-November, Washington had settled upon a basic outline for his winter dispositions that broadly resembled that of the previous winter. Four Massachusetts brigades were to anchor the left wing along the Hudson, securing West Point, the Clove, and western Connecticut. The remainder of the army, ten brigades, was to winter in northern New Jersey. ${ }^{66}$ For the winter of 1779-1780, the Continental Army ultimately settled upon a camp ground between Morristown and Mendham at a site known as Jockey Hollow. The need for a greater concentration of force, and thereby larger encampment, complicated the army's search for a suitable site, as did Washington's requirement for a more secure locale further distant from New York. Ultimately, Washington and Greene settled upon Jockey Hollow as this site lay far removed from New York and therefore secure from the feared British attack, while also offering suitable

\footnotetext{
${ }^{66}$ Washington to Livingston, December 7, 1779, Livingston Papers Volume 3, 255-256.
} 
ground and resources for an encampment. Most importantly, it lay only ten miles further from Trenton than the previous year's Middlebrook encampment, and therefore maintained a logistical feasibility approximating the 1778-1779 site. While inclement weather and financial collapse made the 1779-1780 winter infamous for hunger in the ranks at Jockey Hollow, the army ultimately emerged from that encampment intact. ${ }^{67}$

After 1780, expiring enlistments and the dispatch of forces to the southern theater decreased Washington's manpower in the New York theater well below what it had been in 17781779. Thereby proving less of a logistical burden, the bulk of the Main Army cantoned near West Point for the 1780-81 winter. Nevertheless, three brigades remained in New Jersey, including two from Pennsylvania that re-used the Jockey Hollow camp site until their January 1781 mutiny. The New Jersey Brigade reused the site again in 1781-82, and thus it was not until the winter of 178283 that the state would be free of a Continental presence. ${ }^{68}$

Overall, the course of the war proved correct Washington's decision to quarter the bulk of his forces in northern New Jersey after 1778. While his men did suffer through supply shortages, particularly in 1780 , these problems arose due to currency depreciation and snowfalls that blocked roads leading to camp, not from a shortage of forage or immobilized supply trains. ${ }^{69}$ Soldiers enjoyed healthier conditions within camp due to the placement of their huts on well-drained hillsides, while abundant local timber supplies ensured adequate construction material. In contrast to the logistical advantages the New Jersey environment provided, the state's defensibility endured only limited tests. Britain's New York garrison remained docile through 1778-1779, leaving the

\footnotetext{
67 S. Sydney Bradford, "Hunger Menaces the Revolution, December 1779-January 1780," Maryland Historical Magazine 61 (1966), 1-23.

${ }^{68}$ Lender, "The Cockpit Reconsidered," 60.

${ }^{69}$ See E. Wayne Carp, To Starve the Army at Pleasure: Continental Army Administration and American Political Culture, 1775-1783 (Chapel Hill, NC: University of North Carolina Press, 1984).
} 
Continentals at Middlebrook to withstand the winter months unmolested. Only in June 1780, when Crown forces lunged towards Springfield, did Washington's army fight to defend the approaches to a New Jersey, and then only briefly. Ultimately, Sir Henry Clinton called-off the British attack, and opted instead to target the real strategic prize in the New York region, West Point and the Hudson Highlands. ${ }^{70}$ Thus, over the course of the 1778-1781 period, while northern New Jersey's terrain did provide a protective backstop for the Continental Army, the region's importance to the army transcended its defensibility. Instead, it provided shorter supply lines, greater stocks of local forage, and landscapes that afforded easy construction of winter shelters. Superseding the aims of generals and politicians, New Jersey's environment played the decisive role in the Continental Army's selection of Middlebrook and Morristown for winter quarters.

Steven Elliott holds a B.A. in history from the College of New Jersey, an M.A. in history from Rutgers University-Newark, and is a PhD candidate in history at Temple University. His dissertation, entitled "The Highlands War: Civilians, Soldiers, and Environment in Northern New Jersey, 1777-1781," examines the military, social, and environmental contexts of the Continental Army's presence in New Jersey during the War of Independence. Steven has taught history at Temple University, Burlington County College, and Raritan Valley Community College. Additionally, he has worked as a seasonal ranger at Morristown National Historical Park since 2009.

\footnotetext{
${ }^{70}$ See Thomas Fleming, Forgotten Victory: The Battle for New Jersey, 1780 (New York: Reader's Digest Press, 1973).
} 